\title{
The costs of civil justice and who pays?
}

\section{Andrew Higgins*}

\section{Keywords}

Access to Justice - Costs and Funding - Distributive Justice - Coventry v Lawrence (No 3) [2015] UKSC 50 - Art 6 ECHR

\begin{abstract}
This article examines current debates about delivering access to justice in a shrinking state, specifically the Supreme Court's claim in Coventry v Lawrence that it is impossible to deliver access to justice for all litigants without widely available legal aid, and broader claims that the state is failing in its duty to provide access to justice for all. It argues that the level of public subsidy and the balance between public and private funding for civil justice systems is a question of distributive justice. A critical review of private funding models demonstrates that some have denied access to justice, however requiring litigants to pay for their own access to justice, or to even subsidize access for other litigants, is defensible in principle and practice. Private funding models based on cross subsidization between users could substantially reduce the access to justice 'gap' experienced by many, provided they meet certain criteria.
\end{abstract}

\section{Introduction}

In contemporary debates about the state of civil justice the word 'crisis' is never far away. A steady stream of senior judges and lawyers have noted that legal aid cuts have led to increases in the numbers of unrepresented litigants in the courts, most of whom struggle to adequately represent themselves, and many would be litigants cannot access the system at 
all. ${ }^{1}$ In the recent case of Coventry v Lawrence (No 3), which involved the related problem of the high costs of litigation and the legality of England's system of recoverable conditional fee agreements, the Supreme Court appeared to raise the white flag over the goal of access to justice for all without substantial increases in public funding. In a judgment that was part lament and part challenge to the Government, the President of the Supreme Court, Lord Neuberger, and the Master of the Rolls, Lord Dyson, declared that 'in the absence of a widely accessible civil legal aid system (which had ceased to exist by 1999), it is impossible to devise a fair scheme which promotes access to justice for all litigants. ${ }^{2}$

For as long as governments have sought to reduce state subsidy for civil justice, the legal profession have warned about the dangers of doing so, and some private funding models have been subject to legal challenge. Governments have been largely unmoved by these criticisms and challenges, and have continued to cut public funding and implemented a range of measures designed to substantially shift the burden of funding the justice system from the state to court users. Attention has centred on getting court users to contribute more to the costs of hearing cases (for example, through enhanced court fees) and to contribute more to their own legal costs and those of other court users (for example, through conditional fee agreements, contingency fee agreements and use of cost shifting rules).

The purpose of this paper is to critically examine the Supreme Court's claim that it is impossible to deliver access to justice for all without substantial public subsidy. It considers claims that the state has a duty to underwrite access to justice for all, the meaning of access to

\footnotetext{
* Andrew Higgins, Associate Professor of Civil Procedure, University of Oxford. The author would like to thank Adrian Zuckerman and the two anonymous referees for their comments on this paper. The usual disclaimers apply. Correspondence to Andrew.higgins@law.ox.ac.uk

${ }^{1}$ See eg the Law Society Access to Justice Campaign: 'Access to justice is on the verge of a crisis' (Available at http://www.lawsociety.org.uk/policy-campaigns/campaigns/access-to-justice/)

${ }^{2}$ Coventry v Lawrence No 3 [2015] UKSC 50 [72].
} 
justice, and examines the merits of private funding models for civil justice tried in England and elsewhere.

The paper argues that the optimal level of funding and the precise mix of public and private funding for civil justice is a question of distributive justice, provided the system is consistent the implied right of access to court and the functional nature of legal process. The Supreme Court's claim that a privately funded justice system cannot fairly deliver access to justice for all litigants either adopts an erroneous definition of access to justice and/or is lacking in imagination. Experience has demonstrated that private funding models can deny access to justice for some litigants, and there is a risk that the financial incentives of private providers can distort the legal process. Nonetheless, private funding models, which incorporate a mixture of voluntary and mandatory cross-subsidization between users ${ }^{3}$, can fairly deliver access to justice for many more litigants than is presently the case provided they confer the contractual freedom to pay for one’s own access, and strictly regulate any mandatory cross subsidisation so that the costs are predictable and proportionate.

\section{Part I - Access to Justice in a Shrinking State}

Before getting into the debate as to who should fund civil justice, how, and how much, it might be helpful for readers to get a sense of the scale of the cuts in public funding to the justice system, and its associated costs.

When the Attlee Labour Government created the British Legal Aid system as one of the pillars of the modern welfare state, some $80 \%$ of the population were then eligible for free

\footnotetext{
${ }^{3}$ Voluntary cross subsidization refers to any form of contractual mechanism by which people share with others the actual or possible future costs of access to justice and hence may pay less or more than the market fee for service rates charged for legal assistance. Common examples of voluntary cross subsidisation are contingency fees and legal expenses insurance. Mandatory cross subsidisation, by contrast, is where a litigant is forced to pay for another's access to justice either by court order, or charge levied by the state eg costs orders , or above cost court fees.
} 
legal assistance. ${ }^{4}$ But while other pillars of the welfare state, like the NHS, have become national institutions, Legal Aid has become a poor cousin. Over the past two decades successive governments have pursued policies that transferred the burden of the funding of the justice system from the state to private parties. These policies have been motivated by concerns about the sustainability of the Legal Aid system ${ }^{5}$, and more recently, concerns about the sustainability of public spending generally, combined with growing acceptance of the principle of user pays for public services. ${ }^{6}$

While the Legal Aid system was the most comprehensive in the world it was also the most expensive. A major reason for the high costs is that both the demand for legal aid increased as a broader range of disputes were litigated in the courts, while the average costs of each claim also rose. ${ }^{7}$ By the 1990s the Legal Aid budget had risen to approximately $£ 1.5$ billion pounds annually with around half being spent on civil legal aid, and this budget increased to around $£ 2$ billion pounds in 2013 despite significant cuts in the intervening period. ${ }^{8}$ In an effort to stop the rise in Legal Aid spending, governments reduced fees for legal aid work, and dramatically tightened eligibility criteria. According to Ministry of Justice figures, by 2007 only 29\% of the population were eligible for legal aid, and that number has fallen further still as a result of the cuts introduced by the Cameron Coalition

\footnotetext{
${ }^{4}$ R Jackson, Review of Civil Litigation Costs: Final Report (December, 2009) ch 7 [3.1]

${ }^{5}$ Lord Chancellor 'Access to justice with conditional fees' Consultation Paper (March 1998).

${ }^{6}$ Ministerial Foreword, Enhanced Court Fees - The Government Response to Part 2 of the Consultation, cm8971 (Ministry of Justice, January 2015), p 3

${ }^{7}$ R Jackson 'Review of civil litigation costs: interim report' (May 2009) ch 12 [1.5]; One reason for the increase in the costs of claims was that Legal Aid had the lofty ambition of providing the poor access to legal service at a level of service that meant they were not at a disadvantage compared with their privately funded opponents. However the private market for legal services was far from efficient: legal fees were typically paid by the hour, regardless of outcome and with no upper limit, while many clients had limited ability to judge the value of the service. Legal Aid helped subsidize this opaque market. For discussion see A Zuckerman (ed), Civil Justice in Crisis: Comparative Perspectives of Procedure (OUP Oxford 1999) p 36.

${ }^{8}$ Ibid; Ministry of Justice, Transforming Legal Aid: Next Steps, Consultation Paper (September-November 2013), p 5.

https://consult.justice.gov.uk/digital-communications/transforming-legal-aid-next-steps/consult_view . These figures were still dwarfed by total government spending on health care. According to the Office of National Statistics public sector spending on healthcare totalled £125.5 billion in 2013 and accounted for $83.3 \%$ of total healthcare expenditure in the UK: (see

http://www.ons.gov.uk/peoplepopulationandcommunity/healthandsocialcare/healthcaresystem/articles/expenditu reonhealthcareintheuk/2015-03-26)
} 
Government in 2012. ${ }^{9}$ The numbers of persons receiving legal aid as a result of 2012 reforms fell by half according to the National Audit Office. ${ }^{10}$ Moreover, there is a large category of civil cases for which legally aid is not generally available regardless of means. ${ }^{11}$

The costs of denying legal representation to large numbers of people with a legal problem are not hard to identify. There have been significant increases in the numbers of litigants in person, including cases in which neither party is legally represented. ${ }^{12}$ This increases the financial costs of hearing cases. Litigants in person are unfamiliar with substantive law and court procedure, so judges and court officials spend more time 'knocking the case into shape' and must look beyond the litigant's own advocacy to identify any legal claim or defence. ${ }^{13}$ While there have been measurable increases in the costs to the justice system from dealing with litigants in person ${ }^{14}$, those costs are dwarfed by the savings to the government from reduced legal aid spending. This is partly because some persons are not pursuing their claims or defences at all ${ }^{15}$ while the inability of some litigants in person to adequately represent themselves means they actually take up less court time. In the words of

\footnotetext{
${ }^{9}$ ibid; Legal Aid, Sentencing and Punishment of Offenders Act 2012; Civil Legal Aid (Financial Resources and Payment for Services) Regulations 2013

${ }^{10}$ National Audit Office, Implementing Reforms to Civil Legal Aid HC 784, Session 2014-15, 20 November 2014, p 4. The NAO estimated that some 300-400,000 fewer cases received legal aid funding in 2013-2014, a little less than half the total number of cases that were funded in 2012-2013.

${ }^{11}$ For a list of civil matters for which legal aid may be available see Legal Aid, Sentencing and Punishment of Offenders Act 2012, Schedule 1. The UK Government may be required to provide legal representation in order to protect civil litigants' right to fair trial under ECHR, Art 6 in complex cases where there are important interests at stake: Legal Aid Sentencing and Punishment of Offenders Act 2012, section 10(3). This obligation is based on ECtHR jurisprudence, (see eg Airey v Ireland (App no 6289/73) [1979] EHRR 305 (family law proccedings where the welfare of children was at stake); Steel and Morris v UK (App no 68416/01) (2005) 41 EHRR 22 (defamation proceedings where the right to free speech was in issue)), however the Lord Chancellor's exceptional case funding guidelines were successfully challenged on the basis that it was too strict and thus not compatible with Art 6: Gudanaviciene IS v Director of Legal Aid Casework and the Lord Chancellor [2014] EWCA Civ 1622.

${ }^{12}$ Sir James Munby, President of the Family Division of the High Court in Q v Q [2014] EWFC 31 [11]

${ }^{13}$ Lord Dyson MR, quoted in the Commons Justice Select Committee 'Impact of Changes to Civil Legal Aid under Part 1 of the Legal Aid, Sentencing and Punishment of Offenders Act 2012' (Eighth Report, 4 March 2015) [100]

14 The National Audit Office estimated the 30\% increase in litigants in person in family cases cost the courts an additional £3.4 million: (n 5) p 4

${ }^{15}$ An Australian nation-wide survey into unmet legal need found that half of the respondents had one or more legal problem in the previous 12 months and for almost half of those problems respondents either failed to take legal advice or took no action at all: Law and Justice Foundation of NSW, Legal Australia - Wide Survey, August 2012, xvi- xvii
} 
the Master of Rolls, some Litigants in person are overawed by the courtroom, and just 'freeze'. ${ }^{16}$ The justice deficit experienced by those who cannot access the system, or struggle to represent themselves when they $\mathrm{do}^{17}$, undermines the principle of equality under law and the potential deterrence function of law.

Part II - How much should be invested in the civil justice system?

Lawyers have questioned the legitimacy, and sometimes the legality, of public funding cuts to the civil justice system and the design of some private funding models. ${ }^{18} \mathrm{~A}$ liberal democratic society governed by the rule of law must provide an effective and accessible system for enforcing private rights. ${ }^{19}$ There must be a "floor" in the level of funding for civil justice, below which the justice system would no longer be accessible to the community generally and, effective in upholding the rule of law. On the other hand, if one works with most definitions of the role of the state, there is undoubtedly a ceiling too on the level of subsidy that can be reasonably demanded from the state. The case for greater public support for the justice system is often overstated by lawyers who invoke its constitutional

\footnotetext{
${ }^{16}$ Quoted in Commons Justice Select Committee (n 12) para [101]; There is some evidence from the Ministry of Justice to support this: L Trinder et al, Litigants in Person in Private Family Law Cases (Ministry of Justice Analytical Series, 2014). Substantive hearings where both parties were litigants in person took much less time than cases where both parties were represented, but cases where only one party was represented took longer: pp 55-58

${ }^{17}$ Which increases the risk of cases being decided wrongly or on technicalities. This is arguably a worse outcome than being denied access to court because it still takes up valuable court resources and, as Lord Woolf has noted, can lead to resentment and paranoia on the part of the litigant who feels they have become the victim of a double injustice: R Lowe, 'Lord Woolf: UK legal aid cuts may cause 'extreme' psychological damage' International Bar Association News, 20/03/2013.

${ }^{18} \mathrm{~T}$ Judd, 'UK's top judge Lord Neuberger, the Supreme Court President, attacks Government on legal aid cuts, secret courts and human rights threats' The Independent, 5 March 2013 (Available at: http://www.independent.co.uk/news/uk/politics/uks-top-judge-lord-neuberger-the-supreme-court-presidentattacks-government-on-legal-aid-cuts-secret-courts-and-human-rights-threats-8520105.html )

${ }^{19}$ Blackstone wrote, 'A third subordinate right of every Englishman is that of applying to the courts of justice for redress of injuries. Since the law is in England supreme arbiter of every man's life, liberty, and property, courts of justice must at all times be open to the subject...': William Blackstone, Commentaries on the Laws of England (W. Morrison edn, Routledge 2001) p 105.
} 
function as a reason for giving it a priority claim on public funds. In 2013 Lord Neuberger

stated extra curially:

The media may concentrate on the government's health, social security and education programmes, but these are both secondary, and rather recent, functions of government. The defence of the realm from abroad and maintaining the rule of law at home are the two sole traditional duties of a government. More importantly, they are fundamental. If we are not free from invasion, or the rule of law breaks down, then social security, health, and education become valueless, or at any rate very severely devalued. ${ }^{20}$

Lawyers are uniquely placed to convert policy questions regarding the allocation of public resources into legal questions said to engage constitutional rights. ${ }^{21}$ In . But whether the question is framed as a legal or policy one, it does not change the essentially distributive nature of the exercise: allocating public money to fund services provided by the state including legal assistance.. As Gardner has argued in relation to legal rights themselves:

The law is selecting some people for a measure of official support in their personal affairs that most other clients of the welfare state can only dream of. Even among those who have been wronged, not all can possibly enjoy this level of support in putting things right, and the question is always live of who should be the privileged ones who qualify for it. ${ }^{22}$

The distributive justice enquiry operates at two levels here: first, the allocation of the burden of funding civil justice between members of the public, and secondly, the total level of funding to the system. On the first score, the allocation of the funding burden has become virtually impossible to defend due to the growth of the 'missing middle' funding civil justice: this group, which comprises the larger part of the population according to the Civil Justice

\footnotetext{
${ }^{20}$ Lord Neuberger 'Justice in an Age of Austerity' (Tom Sargant Memorial Lecture, 15 October 2013) pp 2-3. (Available at https://www.supremecourt.uk/docs/speech-131015.pdf).

${ }^{21}$ One example highlighted by Lord Sumption in a speech entitled 'The Limits of the Law' (27th Sultan Azlan Shah Lecture, Kuala Lumpur, 20 November 2013) pp 4-6 is $R v$ Lord Chancellor ex parte Witham [1998] QB 575. Ib that case the Divisional Court declared regulations abolishing court fee remissions for the poor to be unconstitutional without specific statutory authority because they infringed the right of access to court. Court fees in British Columbia have also been struck down as unconstitutional by the Canadian Supreme Court in Trial Lawyers Association of British Columbia v Attorney-General of British Columbia [2014] 3 SCR 31.

${ }^{22}$ J Gardner, 'What is Tort Law For? Part 2 - The Place of Distributive Justice' Oxford Legal Research Paper Series, Paper number 62/2013 (May 2013), p 10
} 
Council, funds the justice system through taxation, but are neither eligible for legal aid nor able to afford private legal assistance. ${ }^{23}$

Imposing the burden of funding justice for the poor on those who cannot access the same system, even if they have the same legal need, might be justified if legal aid for the poor is not designed to protect people's legal rights, but instead represents another form of financial assistance to the poor. If this is correct, it squarely raises the second distributive justice question: are there better ways to provide support to the poor than funding legal assistance? Should, for example, the state cut funding for drug treatment programs to increase the legal assistance for persons involved in criminal or civil proceedings that are partly attributable to drug dependency? Or should it spend more money on education and employment programs for those with limited qualifications and skills who develop legal problems? Legal rights may have greater value for the poor than the financial value of the right, partly because some legal problems can have serious life impacts that disproportionately affect the poor. ${ }^{24}$ Yet the same must be true of other public services like education that can help address serious life problems.

Intuitively recognising that the best defence of public legal aid lies not in the economic value of the aid, but the importance of protecting legal rights, lawyers argue that legal assistance ought to be available to all who need it even if that requires imposing additional taxes, or reducing other government services. However the moral basis for prioritizing legal interests over other public services is not axiomatic. We can safely assume

\footnotetext{
${ }^{23}$ Civil Justice Council, ‘Access to Justice for Litigants in Person’ (November 2011) para [14] (Available at https://www.judiciary.gov.uk/wp-content/uploads/2014/05/report-on-access-to-justice-for-litigants-in-personnov2011.pdf)

${ }^{24}$ According to an Australian survey into unmet legal need carried , the majority of people with legal problems ${ }^{24}$ had a 'substantial problem' that had a severe or moderate impact on everyday life leading to income loss or financial strain, stress-related illness, physical illness and relationship breakdowns and a need to move home. Moreover, disadvantaged people were particularly vulnerable to substantial and multiple legal problems: Law and Justice Foundation of NSW (n 16), xiv-xvii. Research in England has produced similar findings: see eg G Cookson, 'Unintended Consequences: the cost of the Government's Legal Aid Reforms: A Report for The Law Society of England \& Wales’ (November 2011) (Available at http://www.kcl.ac.uk/campuslife/student/news/stories/UnintendedConsequences-FinalReport.pdf).
} 
that the President of the Royal College of Physicians has not delivered an address on public health declaring that health care is secondary to the rule of law. One argument advanced for legal exceptionalism is that because law is a creation of the state, the state is responsible for making legal knowledge and institutions available to all. ${ }^{25}$ Yet even here there is no clear delineation between law and other goods: for example, the state's existence, its borders, and exercise of its powers can also affect public health positively and negatively. There are also risks in seeking to create a hierarchy of interests that the state ought to protect, with justice at or near the top. While Lord Neuberger coupled law and security as the state's primary obligations, some politicians and even some lawyers argue that the state's primary duty is to provide security, and where law interferes with that goal it must give way. ${ }^{26}$ Lawyers typically respond that law is vital to our security, our values and our prosperity, but most public services promote these goals. The happy fact is that law features on most people's definition of the good life, but so too do other services that are subsidized by the state.

To date, no legal scholar has developed a credible theory of justice that requires the state to underwrite every legal dispute. Justice, both in its legal form and as a broader claim about how society should be ordered, has an inherent resource dimension. ${ }^{27}$

But if the state is not required to underwrite the civil justice system for all, then how much is enough? If the allocation of resources to civil justice is purely a question of distributive justice then answering this question would require us to adopt a theory of the state. Such a task is beyond the scope of this paper, but one critical part of the "how much" inquiry this paper does seek to address, is to define what it is we are funding: what do we

\footnotetext{
${ }^{25}$ E Cohn, 'Legal Aid for the Poor: A Study in Comparative Law and Legal Reform' (1943) 59 Law Quarterly Review 250, 256; D Luban, Lawyers and Justice: An Ethical Study (Princeton University Press, 1988) 246-8

${ }^{26}$ In this context it makes no difference whether one interest is pursued in preference to the other, or receives a greater share of public resources than the other. By way of example, during the Bush Administration's 'war on terror', government lawyers provided legal opinions that, because of the nature of the threat, a number of international legal rules and domestic constitutional guarantees did not apply or could be dispensed with (see John Yoo, former Deputy Assistant Attorney General in the Office of Legal Counsel of the Justice Department from 2001 to 2003 defending the approach at 'Commentary: Behind the 'torture memos' 4 January 2005, available at www.berkeley.edu/news/media/releases/2005/01/05_johnyoo.shtml)

${ }^{27}$ R Dworkin, A Matter of Principle (Clarendon Press 1985) p 92
} 
mean by access to justice? The civil justice system comprises the legal process for determining disputes and upholding rights, and the rules on accessing this procedure. Legal process has certain qualitative characteristics that distinguish it from other dispute resolution services. Whereas the legitimacy of some dispute resolution services depend on parties' consent to the outcome eg mediation, or consent to the process eg arbitration, the legitimacy of legal process derives from the court's role in protecting rights and upholding the law. As a consequence it is possible to identify, as a matter of law, how much legal process is due in any particular case. There is considerable constitutional jurisprudence in England, the European Court of Human Rights, and the U.S Supreme Court as to the meaning of a fair trial, or in functional terms, 'how much process' is due to litigants under law? ${ }^{28}$

Legal process is meant to deliver judgments that accurately apply the law to the true facts of the dispute. Delivering correct judgments, however, does not fully describe the court's function as law enforcers. The rule of law demands the court uphold our rights by providing effective remedies for wrongs. This necessarily depends on considerations of time and cost. A remedy for a wrong has to be administered when it can still do some good. Compensation for personal injuries that comes after the death of the claimant is hardly adequate. The same goes for disputes over property rights, for the sheer uncertainty of subsisting litigation tends to erode the value of property rights. Equally, a judgment for the recovery of debt that costs more than the amount recovered could not provide an adequate remedy to the creditor.

Balancing the objectives of accuracy, time and cost results in a 'three dimensional theory' of procedural justice. ${ }^{29}$ This requires that persons with an arguable claim (or

\footnotetext{
${ }^{28}$ As Isaccharoff puts it: S Issacharoff, Civil Procedure (2 ${ }^{\text {nd }}$ edn, Foundation Press 2009) 7.

${ }^{29}$ A Zuckerman, (n 34) [1.21].
} 
defence) are able to access court at proportionate cost, ${ }^{30}$ within a reasonable time, ${ }^{31}$ and have their claim determined on the merits with reasonable accuracy. ${ }^{32}$ These requirements of procedural justice enjoy formal protection under ECHR Art 6, following the landmark decision of the European Court of Human Rights in Golder $v U K^{33}$ that the right to fair trial necessarily included an implied right of access to court, for otherwise the right would be practically worthless. In subsequent cases the ECHR has delineated the features of the implied right of access to court, emphasising the importance of timely decisions at proportionate cost. ${ }^{34}$

The U.S jurisprudence on the $14^{\text {th }}$ amendment is also instructive in determining how much process is due to litigants when they get to court. In Matthews $v$ Elridge - a challenge to the termination of social security benefits - the US Supreme Court stated that due process generally requires consideration of three distinct factors: the relevant private interests; the risk of an erroneous deprivation of such interest through the procedure used, and the value of any additional or substitute procedures ; and finally, the Government's interest, including the function involved and the fiscal and administrative burdens that different procedures would entail. ${ }^{35}$ This functional conception of due process has been expanded beyond administrative law challenges to ordinary civil disputes. ${ }^{36}$ How much process is due is inherently linked to

\footnotetext{
30 For example, the ECtHR has ruled that the imposition of excessive court fees will amount to violation of the right of access to court: Kreuz v Poland (App No 28249/95) [2001] ECHR 394); Ashingdane v United Kingdom (1985) 7 EHRR 528 [57].

${ }^{31}$ The time dimension of justice is expressly protected by ECHR, art.6.1, which provides that: "In the determination of his civil rights and obligations or of any criminal charge against him, everyone is entitled to a fair and public hearing within a reasonable time.” See also, eg, Unión Alimentaria Sanders SA v Spain (1989) 12 EHRR 24; Scopelliti v Italy (1993) 17 EHRR 493.

${ }^{32}$ Merits are not expressly referred to in Art 6 or even England's Civil Procedure Rules. This is probably explicable by the fact that it is thought so obvious it does not need stating. There is, of course, no meta-test to assess the correctness of a court's decision, hence law's classification as imperfect procedural justice. All a court can do is follow a process that provides a reasonable prospect of reaching a correct decision.

33 Golder v UK (1979-1980) 1 EHRR 524.

34 See footnotes XXX

${ }^{35}$ Matthews v Eldridge 424 US 319 (1976) 335

${ }^{36}$ Connecticut v Doehr 501 US 1 (1991) 10
} 
the value of the rights in question, the capacity of the procedure or other procedures to avoid error, and the public and private interest in timely and affordable resolution. ${ }^{37}$

One might be able to further than stating that due process is an inherent balancing exercise, and define how the balance ought to be struck in each case. If the optimal legal process is measured by reference to the outcomes it delivers, ${ }^{38}$ then the optimal procedure is the one that provides the most accurate judgment which can be delivered at proportionate cost and within a reasonable time. The meaning of proportionate cost and reasonable time has been discussed at length elsewhere ${ }^{39}$, but some reference to the debate on proportionality is necessary to gain an insight into the limits (upper and lower) of how much process is due as a matter of law. There are technical debates as to whether proportionality should be calculated exclusively by reference to the financial value of the dispute or be adjusted to take account of other interests including, for example, if its resolution might affect other similarly situated persons. The former approach may mean important interests are not given due weight; the latter approach may lead to in-determinancy and undermine the goal of making the costs of justice affordable.

This dilemma informs procedural debates about the legitimacy of facilitating, or requiring, the aggregation of disputes eg class actions, as well as the scope of intervener and amicus curiae rules that allow third parties to address the court on any wider interests in the dispute. ${ }^{40}$ These procedural devices help ensure that all interested persons are effectively before the court, or that their legal interests are adequately represented, so that a court has a

\footnotetext{
${ }^{37}$ Hilao v Estate of Marcos 103 F.3d 767, 786 (9th Cir. 1996)

${ }^{38}$ This is sometimes referred to as a utilitarian theory of procedure. There are alternative theories that place greater weight on civil justice's role in promoting dignitarian process values: see eg: R Summers 'Evaluating and Improving Legal Processes-A Plea for Process Values’ (1974) 60 Cornell L Rev 1. But even process oriented theories are not detached from considerations of cost and time.

${ }^{39}$ For discussion see A Higgins and A Zuckerman, 'Lord Justice Briggs' "SWOT” analysis underlines English law's troubled relationship with proportionate costs' (2017) 36 Civil Justice Quarterly 1; J Sorabji, Prospects for proportionality: Jackson implementation, (2013) 32 CJQ 213

${ }^{40}$ See eg Supreme Court Rules 2009, rules 15 and 26.
} 
better grasp of what is at stake in the case and can allocate a proportionate amount of resources to its resolution.

While there are debates about the precise methods of calculating proportionate costs, a critical feature of the meaning of proportionate cost, is that the appropriate level of investment is linked to the value of the rights in dispute ${ }^{41}$ and not extrinsic factors such as government spending priorities or other social values. These extrinsic factors are relevant to the distributive justice question of how, and how much, to fund the civil justice system, but proportionate legal costs are a function of the value of legal rights, not a state's social or financial priorities. A state might adopt a system that invests less than a proportionate amount, calculated by reference to the value of the rights, because it wishes to invest more in other services, or because it believes some legal procedures would undermine other rights it values. For example, the importance attached to privacy in Europe is one reason why compulsory disclosure of evidence is more limited in civil law than common law countries, even if this significantly increases the risk of erroneous judgments. ${ }^{42}$ In such cases it can be said that the state has opted for a rougher (and cheaper) cut of civil justice. At some point the level of investment in the process could become too low for the procedure to have any realistic chance of delivering correct outcomes. If this point is crossed, the procedure could no longer qualify as legal process as opposed to another form of dispute resolution. Legal process is not merely the costumes, pleadings and drama of the courtroom even if it is done quickly, cheaply and after hearing both sides. Conversely, at the other end of the scale, requiring litigants to pay more than the value of the right in order to vindicate their legal right does not qualify as 'legal process’ either, even if the investment mightproduce a more

\footnotetext{
${ }^{41}$ There may be of course be substantive law debates about how different rights are valued, but this is a question of substantive law, not the procedural law question how much to invest in determining those rights.

${ }^{42}$ KC Huang, Introducing Discovery into Civil Law (Carolina Academic Press, 2003) 40-42; M Mekki, 'Preuve et vérité en France' [Evidence and Truth in France] (2013, Colloque Journées internationales d'Amsterdam, Pays-Bas et Liège, Belgique [Conference International Days of Amsterdam, Netherlands and Liège, Belgium] http://www.mekki.fr/files/sites/37/2015/07/60_T4_france.pdf>, 824.
} 
accurate judgment. Legal process is not an open ended quest for truth. As we shall see in part III it is this latter problem that beset the Coventry case and the English legal system generally. To summarise, access to justice consists of both an implied right of access to court and due process for litigants once they get there. ${ }^{43}$ We know the approximate upper and lower bounds of 'how much' ought to be invested in the resolution of disputes in order for the process to be classified as legal process. Between these upper and lower bounds there is legitimate scope for the state to make different policy choices about how much will be invested in the process based on distributive justice considerations. But we still have not addressed the question as to who should be paying for that investment and in what proportion, which in turn squarely raises the debate about user pays versus state subsidy. In the next section we examine different policies used by governments to shift the burden of funding of civil justice to users and would be users and their capacity to advance or undermine access to justice.

\section{Part III - Private Funding Models tried in England}

\section{A. Voluntary (Contractual) Cross Subsidization}

Commercial litigation funding is a neat example of contractual cross-subsidization of the costs of access to justice. This can take the form of legal expenses insurance before a dispute has arisen, or conditional or contingency fees and 'after the event' legal expenses insurance. In 'after the event' funding mechanisms, claimants pool the value of their claims to cover the costs of their own access to justice and/or insure themselves against the risk of having to pay

\footnotetext{
${ }^{43}$ This is an exclusively procedural definition of access to justice which does not depend on the content of the substantive law. Many judicial and scholarly attempts to define access to justice often combine it with a definition of the rule of law: see, for example, L Fuller, The Morality of Law (Revised edn, Yale University Press 1969) 81; J Raz, The Authority of Law: Essays on Law and Morality (Clarendon Press 1979) 216-217.
} 
their opponents costs. In the case of 'before the event insurance' would be litigants spread the risk that they will have to make or defend a claim with other would be litigants.

These contractual arrangements are all permitted in England, and in common use in many other legal systems, ${ }^{44}$ but some of them are alleged to be contrary to public policy, and a threat to the administration of justice. The boldest, and weakest, claim made by critics of private funding (who are not necessarily advocates of public funding) is that any third party commercial involvement in the litigation after a dispute has arisen amounts to the “commodification” of justice. In the Australian High Court case of Campbells v Fostif, which considered whether third party litigation funding was contrary to public policy, Heydon and Calinan JJ dissenting, stated: :

[T] he purpose of court proceedings is not to provide a means for third parties to make money by creating, multiplying and stirring up disputes in which those third parties are not involved and which would not otherwise have flared into active controversy but for the efforts of the third parties, by instituting proceedings purportedly to resolve those disputes, by assuming near total control of their conduct, and by manipulating the procedures and orders of the court with the motive, not of resolving the disputes justly, but of making very large profits. ${ }^{45}$

Litigants have always been able to finance litigation through debt (borrowing), but adherents to this view would draw the line at financing litigation through equity.

The proposition that giving third parties a stake in litigation is contrary to public policy is a blinkered view, for it overlooks the fact that all private litigation lawyers have a financial interest in litigation. Lawyers paid by the hour have an interest in the length of the litigation, lawyers paid on contingency fees (i.e. out of any damages awarded) have an interest in the outcome of the litigation and the size of any damages award, and lawyers paid on a conditional fee basis (i.e. where legal fees are calculated on a time or activity basis, but payable only in the event of success) have an interest in both the length and the outcome of

\footnotetext{
${ }^{44}$ For a survey of different approaches in different jurisdictions see C Hodges, S Vogenauer and M Tulibacka, The Costs and Funding of Civil Litigation: A Comparative Perspective (Hart Publishing, 2010)

${ }^{45}$ Campbells Cash and Carry Pty Limited v Fostif Pty Ltd (2006) 229 CLR 386 [266]
} 
the litigation. Unless legal representation is funded and delivered exclusively by public officials, there is always a possibility that legal service providers’ and/or funders’ financial interest in litigation could undermine the quality of service to clients and/or the due administration of justice.

The tension between the public interest in the justice system and the dynamics of the private legal services market provides a strong justification for regulation of both legal service providers and litigation funders. ${ }^{46}$ Regulation reduces the risk of abuse of the legal process and helps protect vulnerable litigants from exploitation. But a rule that would prohibit these funding mechanisms outright, or place onerous restrictions on their use, would deny access to justice for many persons with perfectly valid claims. For these reasons third party litigation funding and/or contingency fees with lawyers are now permitted in many jurisdictions. ${ }^{47}$ Lawyers, ${ }^{48}$ scholars, ${ }^{49}$ and judges ${ }^{50}$ appear united in their belief that the regulatory framework in England is too strict and further reform is needed to promote greater use of commercial funding. ${ }^{51}$

\section{B. Compulsory user pays cross subsidization}

\footnotetext{
${ }^{46}$ Note that third party litigation funding is not formally regulated in England, however there is a system of voluntary self-regulation: The Association of Litigation Funders (ALF) maintains a Code of Conduct for Litigation Funders.

${ }^{47}$ For a survey of different approaches in different jurisdictions see C Hodges, S Vogenauer and M Tulibacka, The Costs and Funding of Civil Litigation: A Comparative Perspective (Hart Publishing, 2010)

${ }^{48}$ Due to the level of restrictions the profession initially dismissed them as 'Don't Bother Agreements': Westminster Policy Forum, Civil justice and the Jackson reforms - next steps for an evolving framework (Royal Society, Carlton House) 2 April 2014

49 See eg R Mulheron, 'The Damages-Based Agreements Regulations 2013: Some conundrums in the 'Brave New World' of funding' (2013) 32 CJQ 241

${ }^{50} \mathrm{R}$ Jackson, 'Fixing and funding the costs of civil litigation' (2015) 34 CJQ 42

51 The Damages Based Agreements Regulations 2013 place statutory caps on the size of any contingency fee: namely 25\% for personal injury matters, 35\% for employment matters and 50\% for other matters (eg commercial matters). These caps include the costs recoverable from an opponent so that in many cases either no “success" fee at all, or only very small success fees, could be recovered from clients. Moreover if the recoverable fees exceed the amounts of the statutory caps, then under the indemnity principle that the lawyer can only recover fees chargeable to the client, the losing litigant is not obliged to pay more than the statutory caps either so that a contingency agreement may actually leave lawyers worse off than a conditional fee agreement: see Mulheron (n 61) 243-245
} 
Lawmakers have not been content to rely solely on voluntary user pays cross subsidization as an alternative to funding access to justice. They have also adopted models based on compulsory cross subsidization between litigants i.e. where a litigant is forced to pay for another's access to justice. An excellent example is the UK government's decision to introduce 'enhanced’ court fees.

From March 2015, the UK Government set the fee to issue proceedings for money claims at $5 \%$ of the value of the claim for claims worth $£ 10,000$ or more, capped at a maximum fee of $£ 10,000{ }^{52}$ The impact of the new fees are still being reviewed, ${ }^{53}$ but one clear intended consequence is that many litigants are now paying court fees above the cost to the public purse of dealing with the dispute. ${ }^{54}$ The UK Government says it is committed to reinvesting the surplus it collects from enhanced court fees back into the civil justice system, including to help fund fee remissions for the poor. ${ }^{55}$ The Minister for Courts and Legal Aid, Shaleish Vara, stated in the Ministerial Foreword to the Government's response to the consultation on enhanced court fees:

If we are to protect access to justice, and all the benefits that brings, I am convinced that there is no alternative but to look to those who use the courts to contribute more towards their running costs where they can afford to do so. ${ }^{56}$

In effect the Government is seeking to shift the burden of funding the civil justice system from an imperfect progressive tax system to an imperfect progressive user pays system. ${ }^{57}$

\footnotetext{
${ }^{52}$ The changes were introduced by The Civil Proceedings and Family Proceedings Fees (Amendment) Order 2015, SI 2015/576. The power of the Lord Chancellor to increase fees above cost is conferred by section 180 of Anti-Social Behaviour Crime and Policing Act 2014.

53 There was an expected spike in claims before the fees came into effect, followed by a reduction. The government asserts, and the judiciary broadly accepts, that it is too soon to tell whether the reduction is due to the spike or the new fees. For discussion see: House of Commons Justice Committee, Courts and Tribunals Fees, Second Report of Session 2016-17, HC 167 (20 June 2016)

${ }^{54}$ In announcing the decision the Government acknowledged that in some high value claims the new fees would bear little resemblance to the costs of resolving the dispute: Ministerial Foreword, 'Enhanced Court Fees - The Government Response to Part 2 of the Consultation', cm8971, January 2015 (Ministry of Justice) p 14. For lower value claims of $£ 10,000$ or less a $5 \%$ fee would be lower than current fees designed to provide full cost recovery, hence the $5 \%$ fee is applied only to claims above $£ 10,000$ : 'Court Fees: Proposals for Reform', cm8751, December 2013 (Ministry of Justice) pp 30-31.

${ }^{55}$ Ministerial Foreword, 'Enhanced Court Fees - The Government Response to Part 2 of the Consultation', cm8971, January 2015 (Ministry of Justice) p 3.

${ }^{56}$ ibid
} 
Yet the introduction of above cost fees for some users was strongly opposed by both branches of the profession. In a statement opposing the fees, the Law Society stated:

It is wrong in principle for the court service to be treated as a profit centre - the courts have a vital social function which it is for the State to provide, and should not be treated as a commercial activity to subsidize other work. ${ }^{58}$

Despite asserting the courts should not be treated as a commercial activity, even though private lawyers are, by definition, engaged in a commercial activity, the Law Society also claimed enhance fees would adversely affect London as a centre for international dispute resolution. ${ }^{59}$ The senior English judiciary also expressed serious reservations about enhanced fees. The senior judiciary called for a public debate on the 'major issues of policy' raised by enhanced fees including:

How is the position of the courts in providing access to justice for all and maintaining the rule of law for the benefit of all to be reconciled with the proposition that they should be financed only by those who actually use them? ...Should fee remissions for those who cannot afford to pay fees be financed by other users of the court? ${ }^{60}$

It is possible to reject the senior judiciary's (not so subtly expressed) preferred policy outcomes. There is nothing unfair in requiring some court users to pay, at the point of use, for others’ access to justice, subject to some crucial caveats.

Some lawyers and judges have historically resisted singling out court users to make a bigger contribution to even their own access to justice, again citing the court's constitutional

\footnotetext{
57 'Court Fees - Proposals for Reform’, (n X) pp 6-7, 27; ‘Impact Assessment - Enhanced Court Fees’ 16 January 2015 (Ministry of Justice) p 1.

${ }^{58}$ See Law Society Submission, 14 February 2014, available at http://www.lawsociety.org.uk/policycampaigns/consultation-responses/documents/consultation-on-court-fee-proposal-reforms-law-societyresponse/; The Bar Council Submission was to similar effect, January 2014, available at http://www.barcouncil.org.uk/media/283036/bar_council_response_to_moj_consultation_on_court_fees_propos als_for_reform.pdf.

59 'Enhanced Court Fees - The Law Society Response’ 2 March 2015. https://www.lawsociety.org.uk/policycampaigns/consultation-responses/enhanced-court-fees/

${ }^{60}$ Response of the Senior Judiciary of England \& Wales (n 33) para [24].
} 
function. For example, in its submission on enhanced court fees, the senior judiciary, endorsed a 1997 speech given by Sir Richard Scott VC in which he stated:

A policy which treats the civil justice system merely as a service to be offered at cost in the market place, and to be paid for by those who choose to use it, profoundly and dangerously mistakes the nature of the system and its constitutional function. ${ }^{61}$

There appear to be two propositions underpinning this view, one of which is correct, and the other is contestable. The first is that to regard court adjudication as simply one form of private dispute resolution is to debase its constitutional function. ${ }^{62}$ Court cases, pistol duels and counselling sessions might be equally effective means of dispute resolution but there is no moral equivalence in their aims. Only court adjudication is dedicated to protecting legal rights and upholding the rule of law. But this (correct) claim says nothing about how court adjudication should be funded. The second proposition goes further and argues that because the civil justice system is a vital public service that benefits everyone, it should be paid for by everyone through general taxation.

This second claim can be tackled in different ways. There is no constitutional threat in requiring a litigant qua litigant to pay for the justice system rather than to make them pay qua taxpayer, all else equal. There is no legal principle that requires that users of the system are subsidized by those who do not use it. Not only is the total level of subsidy to the justice system a question of distributive justice, so too is the balance between public and private subsidy for those who use the system. It might be said that there is a difference between asking users to pay for the service they use, and forcing litigants to subsidise others' access to justice as a condition of exercising their own right of access. But forced cross subsidisation between litigants is by itself no more arbitrary than taxation rules that require different

\footnotetext{
${ }^{61}$ Keith Tucker Lecture to the Kent Law Society, $13^{\text {th }}$ March 1997 quoted in Response of the Senior Judiciary of England \& Wales to the Government consultation on 'Court Fees - Proposals for Reform', 4 February 2014, (Available at https://www.judiciary.gov.uk/wp-content/uploads/JCO/Documents/Consultations/seniorjudiciary-response-court-fees-proposals-for-reform.pdf.)

62 Professor Dame Hazel Genn, The Hamlyn Lectures 2008, Judging Civil Justice (CUP 2009) 20-24, 134; A

Zuckerman, On Civil Procedure (3rd edn, OUP 2013) para [1.5].
} 
taxpayers to pay different tax rates, allow them to reduce their tax liability or to pay no tax at all. Both taxation and user pays rules can be progressive or regressive, efficient or inefficient, by design or effect. ${ }^{63}$ Public funding and private funding of the justice system derive largely from the same source: the public who access or have the right to access the courts. Of course, not all taxpayers are litigants and not all litigants are taxpayers, so shifting to a user pays system can change the identity of the funders, not just their respective contributions. But such changes could produce a more equitable funding burden. For example, some research suggests that a large majority of litigants in the Commercial Court are foreign registered companies and business people, who elect to resolve their legal disputes in English courts, which have a well-deserved reputation for excellence and independence. ${ }^{64}$ Yet foreign litigants using our courts have historically contributed little to the funding of the system. Moreover, although the justice system benefits everyone through the development of the law, it is also undeniable that private litigants derive substantial benefits in the form of enforceable judgments, or settlements negotiated against the possibility of formal court adjudication. The paradox in the access to justice debate is that while some parts of the civil justice system are extremely profitable and gold standard (The UK legal services market had an estimated turnover of $£ 30.6$ billion in 2013), ${ }^{65}$ other parts of the system operate on stretched resources, and are inaccessible to many. Against this background, it is hardly surprising that governments would explore options for greater cross-subsidization between different parts of the system. Despite the widespread opposition to enhanced fees in principle, there are precedents for funding public services by means of differential fee structures including above

\footnotetext{
${ }^{63}$ As Gardner has observed: 'Even for those who say that 'user pays' is the best (most just) solution, there is no doubt that such problems of how to allocate scarce medical and social services fall under the heading of distributive justice. Why doubt that the same is true regarding the allocation of scarce judicial services?' 'What is Tort Law For? Part 2 - The Place of Distributive Justice’ Oxford Legal Research Paper Series, Paper number 62/2013 (May 2013), p 10

${ }^{64}$ One study suggested the number was as high as $75 \%$, and the majority of those were from outside the European Union: see J Croft, 'Three-quarters of litigants in UK commercial court are foreign' The Financial Times, 29 May 2014.

65 The City UK, 'UK Legal Services 2015’ (Available at https://www.thecityuk.com/research/uk-legal-services2015-legal-excellence-internationally-renowned/)
} 
cost fees for some users e.g. education. Even the Law Society has advanced proposals for compulsory cross-subsidisation of the justice system by alcohol consumers. In its access to justice review in 2010, Law Society recommended an increase in sales tax on alcohol to pay for legal aid. ${ }^{66}$ Once we start singling out some sections of the community to make a greater contribution to the justice system it is no big leap to ask court users to make a greater contribution too.

There is, however, a crucial caveat to the claim that because the distribution of the funding burden for the civil justice system is a question of distributive justice, it is permissible to demand more from court users. As we saw from our discussion in Part II, all litigants have an implied right of access to court entitling them to access the system at proportionate cost. Accordingly, there are practical limits on what can be demanded from users of the system qua 'user', lest the demands undermine their own right of access to justice. There is no danger that the Government's system of enhanced fees would violate this right of access precisely because the fees are calculated as a fixed and small proportion of the value of the dispute i.e. the fees are consistent with the definition of proportionate cost, even if some of the revenue collected is used to fund other disputes. ${ }^{67}$

\section{Compulsory loser pays cross subsidization}

The strong opposition amongst lawyers to the Government's enhanced courts fees might lead the reader to think that the policy of mandatory cross subsidization between users was a

\footnotetext{
${ }^{66}$ The Law Society, Access to Justice Review: Final Report (November 2010) p 38. The Society argued that many criminal offences were alcohol related. That is true, but the NHS also treats many alcohol related accidents and illnesses at enormous expense - $£ 3.5$ billion a year according to Public Health England, Alcohol Treatment in England 2013-2014, October 2014, p 3 It also called for a levy on the financial services industry to cover the costs of fraud cases.

${ }^{67}$ The Government points out that $5 \%$ of the value of the claim represents a small fraction of the overall costs of litigation, which are predominantly made up of legal fees: $\mathrm{N}$ Holborne, 'Vara rejects Lord Dyson's criticism of enhanced court fees' Legal Futures, 9 February 2016 (Available at http://www.legalfutures.co.uk/latestnews/vara-rejects-lord-dysons-criticism-of-enhanced-court-fees).
} 
departure from existing practice, but the practice is well entrenched. For centuries English law has adopted a system of loser pays cross subsidization whereby the loser of the case is ordered to pay the winner's legal fees. The practice is so established it is referred to in the rules of procedure as 'the general rule'. ${ }^{68}$ Historically, however, cost shifting was never rationalised as a mechanism for distributing the burden of funding access to justice amongst users. Instead, it was deemed that the loser had a moral and legal obligation to compensate the winner for successfully enforcing their legal rights or defending their legal position. In other words, lawyers have traditionally viewed the prism of cost shifting through the lens of corrective justice rather than distributive justice. This is an important fault-line in the funding civil justice debate, for if corrective justice links the doing and suffering of harm between the wrongdoer and their victim ${ }^{69}$, it means that cost shifting cannot be justified except as between the wrongdoer ( loser) and their victim ( winner) and only up to the amount of the loss suffered by the victim (i.e. the legal costs incurred by them). But even reading this sentence should draw attention to a basic flaw in the corrective justice rationale for cost shifting- merely winning or losing a case does not make the winner a victim and the loser a wrongdoer. In the vast majority of civil claims the unsuccessful litigant has committed no wrong against their opponent, or anyone else, in seeking to enforce or defend their legal rights. Indeed, they are exercising their right of access to court as protected by ECHR, art.6. The question of who should pay for the exercise of these constitutional rights is quite separate from the question of whether one party has wrongly infringed the rights of another and, if so, the full value of those rights in damages. Litigation can be conducted unlawfully, it can be conducted for an improper purpose, or the claims or defences may be so weak that they do not warrant court adjudication. There are specific rules to deal with all these scenarios. But a litigant who advances a case that merits court adjudication cannot be

\footnotetext{
${ }^{68} \mathrm{CPR} 44.2(2)(\mathrm{a})$

${ }^{69} \mathrm{E}$ Weinrib, The Idea of Private Law (OUP revised edn 2012) p 73
} 
said to have wronged his opponent merely because the court has held against them.. ${ }^{70}$ If the corrective justice rationale for cost shifting is abandoned, cost shifting could then be viewed as just another method of compulsory cross subsidization to fairly and efficiently distribute the costs of access to justice.

Not only is a distributive justice approach to cost shifting legitimate in principle, in practice it is a necessity because a loser pays system based on notions of corrective justice seriously distorts the litigation process, and make the costs of access to justice both unpredictable and unaffordable. The moral hazard built into full cost shifting from loser to winner is obvious. Allowing litigants to enter into fee agreements with their lawyers which can be shifted to a third party - their opponent - depending on the outcome of the case, gives litigants the power to dramatically 'ratchet up' the potential liability of their opponent. And the only way the opponent can avoid this additional liability is to either settle or invest even more in the dispute in an effort to avoid losing. ${ }^{71} \mathrm{~A}$ case can be quickly transformed from a dispute about the underlying legal claim, into an attempt to avoid paying the costs incurred by an opponent, which often exceed the amount in dispute. The mass of litigation in England dedicated to the costs of litigation is testament to the distorting effects of full cost shifting. As Lord Justice Jackson put it, the 'inevitable result' of 'unrestrained costs shifting' is a system that is 'exorbitantly expensive." 72

The system of recoverable CFAs, which was the subject of the Coventry case, illustrates the point all too well. ${ }^{73}$ This system was introduced by the Blair Labour Government as an alternative means to Legal Aid funding. It combined full loser pays cost shifting with conditional fee agreements that allowed litigants to agree 'success fees' of up to

\footnotetext{
${ }^{70}$ A Zuckerman (n 35) [27.383]

${ }^{71}$ The problem is made worse by the psychological phenomenon of people being willing to risk more to avoid a loss than they are willing to risk to make a gain: A Tversky and D Kahneman, The Framing of Decisions and the Psychology of Choice, 211 Science 453 (1981)

${ }^{72}$ R Jackson, 'Fixed Costs - The Time Has Come’ IPA Annual Lecture, 28 January 2016

${ }^{73}$ Coventry v Lawrence (No 3) (n 2)
} 
$100 \%$ of base costs with their lawyers, and legal expenses insurance with their insurers, as a method of funding their cases without paying legal fees upfront, and not at all in the event of losing. ${ }^{74}$ However, a system that provided contingent loans for legal costs at an interest rate of up to $100 \%$, would leave successful claimants with much less compensation after paying their lawyer's success fee. This was deemed unacceptable, so the Government made both the success fee and the premium for litigation costs insurance (to protect litigants against an adverse costs order) recoverable from the losing opponent, ${ }^{75}$ CFAs were available to any party, including defendants, regardless of their means, ${ }^{76}$ and available in any proceedings for resolving disputes excluding criminal and family law matters. ${ }^{77}$

This system represented full cost shifting on steroids. Not only were the actual costs of the case shifted from loser to winner, so too was the risk premium associated with losing the case. Because the success fee could be up to $100 \%$ of a litigant's reasonable costs, it was possible to double your opponent's costs liability at the stroke of a pen. Moreover, because the size of the lawyer's success fee and insurer's ATE premium was linked to the level of risk in pursuing a case, the stronger a party's case on the merits, the more costs they had to pay if they ended up losing to a CFA funded opponent. .

\footnotetext{
${ }^{74}$ Courts and Legal Services Act 1990, s 58, which came into force in 1995

${ }^{75}$ Lord Chancellor 'Access to justice with conditional fees' Consultation Paper (March 1998); Access to Justice Act 1999, ss 27and 29. This led to a major expansion in the ATE insurance market: R Jackson, Review of Civil Litigation Costs: Preliminary Report (n 7) chapter 14, para [1.2]. At the time of Jackson's report there were 36 ATE providers offering 54 different products, suggesting that legal expenses insurance can be just as profitable in dysfunctional systems as functional ones. On the other hand, the unpredictability of legal costs in England makes keeping the costs of BTE insurance affordable and attractive a considerable challenge, and as a consequence the English BTE market is much smaller: see Jackson, Preliminary Report (n 7) chapter 13 para [1.3].

${ }^{76}$ Campbell v MGN Limited [2004] UKHL 22, [2004] 2 AC 457. In this case the model, Naomi Campbell, conducted her privacy claim using a conditional fee agreement.

${ }^{77}$ Courts and Legal Services Act 1990, s58A(1)
} 
The perverse incentives created by recoverable CFAs with the inevitable increase in legal costs, ${ }^{78}$ led the ECtHR to find that the chilling effect it had on a media defendant, who was being sued by a CFA funded claimant for breaches of their right to privacy under ECHR Art 8, violated the right to freedom of expression under art 10 of the ECHR. ${ }^{79}$ Therefore it is not surprising that when the defendants in the Coventry case were presented with a costs bill in which the claimants' lawyer's success fee alone was higher than the financial value of the claimants' claim ${ }^{80}$, they, too, challenged the recoverable CFA regime as a breach of the ECHR. The Coventry case concerned an “ordinary” nuisance claim between the owners of a bungalow of relatively modest value and the organisers of car races at a nearby speedway, hence the challenge focused principally on the grounds of an alleged breach of the right to fair trial under Art $6 .{ }^{81}$

While all the justices of the Supreme Court were highly critical of the recoverable CFA system, it held by a majority that it was not a breach of the right to fair trial. The Majority distinguished Coventry from the ECTHR's decision in MGN. In their joint judgment Lord Neuberger and Lord Dyson MR (with whom Lord Sumption and Lord Carnwath agreed) ${ }^{82}$ stated that $M G N$ concerned the balance between two competing convention rights articles 8 and 10. By contrast, where the legal claim was that a system designed to promote access to justice breached a person’s right of access to justice, the balancing of Article 6

\footnotetext{
${ }^{78}$ According to the Lord Chancellor, in a speech given on 21September 2008, there had been a 'scandalous' increase in claimant lawyers' costs: cited in Lord Justice Jackson's Costs Review (n 4) ch1 [1.3]. Yet to ensure the system achieved its objectives i.e. to protect access for all claimants and to protect "full compensation" for successful claimants, the Court of Appeal upheld the ability of litigants to recover disproportionate costs from their defeated opponents, provided the costs were necessarily incurred: Home Office v Lownds [2002] EWCA Civ 365; Rogers v Merthyr Tydfil County Borough Council [2006] EWCA Civ 1134, [2007] 1 WLR 808 [105][106].

${ }^{79}$ MGN Limited v United Kingdom (App no. 39401/04) [2011] ECHR 66.

${ }^{80}$ Coventry v Lawrence (No 3) (n 2) [4]-[7].

${ }^{81}$ The Defendants also alleged a breach of article 1 of the First Protocol to the Convention but this challenge was dismissed on the same grounds as the challenge to Art 6: see [95].

${ }^{82}$ Lord Mance delivered a short concurring judgment.
} 
rights of different litigants was an exercise of a 'wholly different character. ${ }^{83}$ The Majority made clear that the constitutional question was not whether the scheme was fair, or could be made fairer, but whether it was a disproportionate way of achieving the legitimate aim. ${ }^{84}$ In a candidly utilitarian analysis they stated that 'in a number of individual cases...the scheme interfered with a defendant's right of access to justice', however, in considering the compatibility of the system with Art 6 'it is necessary to concentrate on the scheme as a whole. ${ }^{85}$ On the whole, the scheme was a rational and coherent means of pursuing a legitimate objective: to achieve the widest access to legal services for civil litigation funded by the private sector rather than public (legal aid) funds. ${ }^{86} \cdot{ }^{87}$

Lord Clarke (with whom Lady Hale agreed) dissented in Coventry. Accepting that harsh results in individual cases were not necessarily fatal to the scheme, ${ }^{88}$ the Minority held the scheme breached Art 6 because it was arbitrary. The rules singled out from the class of unsuccessful litigants a subset of those who happened to have been opposed by litigants on CFAs and imposed on them the burden of funding other unsuccessful cases which did not involve them, regardless of the merits of their decision to defend the case, whether the costs payable were proportionate, or the financial circumstances of the payer. ${ }^{89}$

Although the Supreme Court divided as to whether the design of the system breached Art 6, there appears to have been agreement that it was inevitable, or at least acceptable, that even a well-designed civil justice system could breach the right of access to justice for some

\footnotetext{
83 ibid [50]-[52]

${ }^{84}$ ibid [56]

85 ibid [62]-[63], [83]

${ }^{86}$ ibid [64]

${ }^{87}$ The Majority did not rest their decision solely on the margin of appreciation accorded to governments making difficult policy choices. They went on to critically review the scheme and the alternatives proposed by the defendant including ed a loser's levy designed to more fairly distribute the legal costs of all successful litigants among all unsuccessful litigants, and a general discretion in the court to consider all the circumstances of the case including the parties' financial positions. The proposed alternatives were dismissed as unworkable or uncertain and conducive to satellite litigation: ibid [73]-[79]

88 ibid [83]

${ }^{89}$ ibid [112]
} 
litigants, unless the cost is subsidized by the state. This claim is scrutinised in the next part.

To conclude our discussion on compulsory loser pays cross subsidisation, the English

experience demonstrates that full cost shifting based on corrective justice logic invariably

leads to moral hazard and distortions, and nor is it defensible in principle. Viewing the

allocation of costs as a question of distributive justice does not, of course, guarantee an

equitable or efficient funding system, but it becomes practically possible to avoid the

distortions of cost shifting because it does not require a cost system to be designed around the

question of who won, or fully compensating the successful litigant for the cost of winning.

\section{Part IV - The challenges of designing a private funding model for civil justice}

It is not difficult to see why the Supreme Court in Coventry was moved to make a barely disguised plea to the Government for additional public subsidy for the justice system. The case tells a sorry tale about the costs of civil justice in England. The Majority reasoned that one of the opposing sides in the Coventry case - be it the claimants or defendants - were always going to be denied access to justice. In a passage that is depressing for the defeatism it reveals in judicial efforts to keep costs proportionate, the Majority noted that whatever hardship the recoverable CFA regime imposed on the defendants in the Coventry case, that case would not have been viable for the claimants under the new costs regime that replaced it - in which success fees were no longer recoverable and had to be borne by the litigants who used such arrangements. ${ }^{90}$ This is because in Coventry the claimant lawyer's success fee alone exceeded the value of the dispute, so even victory would have left the claimants worse off. In sum, the English legal system has been unable to design a costs system that would

\footnotetext{
${ }^{90} \mathrm{R}$ Jackson (n 4) Major Recommendations, pp xvi -xviii. As part of his reform package, Jackson proposed a series of other reforms that would benefit claimants as a quid pro quo for the abolition of recoverable success fees. This included an increase in general damages, and the introduction of qualified one way cost shifting ('QOCS') in which defendants would pay the claimant's costs if the claimant succeeded, but the claimant would only pay the defendant's costs if they behaved unreasonably. QOCS, however, has only been applied to a limited category of cases, which do not include nuisance claims.
} 
respect both the claimants and defendants right of access to justice in an "ordinary" nuisance claim. At this point in the analysis, the elephant in the room is trumpeting loudly. The use of different funding models, both public and private, over the last three decades, has not changed the fact that legal costs are often unaffordable and disproportionate to the interests in dispute. ${ }^{91}$ The lack of accessibility of the English justice system is not simply a function of reduced state funding, but also the very high costs of litigation with private lawyers. Regrettably, the profession's ire in the access to justice debates has been principally directed at the former phenomenon, not the latter.But is the Supreme Court's plea for much greater public subsidy a recognition of the reality or did they prematurely tap the mat on the viability of private funding models, partly influenced, perhaps, by an ideological preference for public funding? There are two distinct objectives in designing a funding model that does not, by design or effect, deny access to justice for some litigants or would be litigants. The first, which arises regardless of whatever mix of public or private funding is pursued, is to ensure the system is compatible with the requirements of access to justice. The second, which arises if law makers opt for a funding model that relies predominantly or exclusively on private funding, is to make the system both commercially viable for private providers and affordable for paying consumers. These objectives will be discussed in turn drawing on the analysis of the right of access to justice and meaning of legal process in Part II, and contractual and compulsory cross subsidization policies in Part III.

\section{A. Objective 1 - Paying for what? Designing a system that is compatible with the requirements of access to justice}

While it may be trite that a fair funding model must be compatible with the requirements of access to justice, the weakness in the Supreme Court's decision in Coventry was the absence

\footnotetext{
${ }^{91}$ In his costs review, Jackson cited evidence that 73 per cent of all UK households have savings of less than $£ 10,000$. Legal costs for just one litigant can be many times higher than $£ 10,000$ in fully-contested litigation: $R$ Jackson (n 4) Ch 1 [1.2]
} 
of any analysis as to what access to justice for the parties in that case would actually entail. It is possible that the Supreme Court, like the system of recoverable CFAs it was reviewing, might have over-interpreted access to justice to include making the successful litigant "whole” for successfully enforcing or defending the claim. If this was the Supreme Court's thinking, their claim that a private funding system cannot deliver for all litigants is undoubtedly correct. The court process is designed for the purpose of determining disputes between parties with reasonable claims and defences. At least one of the litigants will always lose at trial, in whole or in part, even if they were justified in pursuing their case. The inherent uncertainty as to the outcome, combined with the high costs of success, and higher costs of failure, means that justice is accessible to many litigants only with the assistance of third party funding. Accordingly, there is a public interest in ensuring that litigation funding can be commercially viable due to the vital role that funders play in facilitating access to justice: they always cover, or contribute to, one party's costs of access to justice up front, and often pay both parties' costs of access through adverse cost orders or indemnities against adverse costs orders. ${ }^{92}$ Funders must be offered reasonable financial rewards for backing successful cases, and be able to cover the costs of unsuccessful cases, so that, across the portfolio of reasonably arguable cases they fund, they can make a reasonable return.

The question for those designing private funding models is then a stark one: who should pay and bear the risk that is inherent to the system and pay for the profit incentive that must be built into it? The commercially obvious answer would be those who enter into the funding arrangements and benefit from them, which in practice would mean successful

\footnotetext{
92 In England a litigation funder is liable to pay adverse costs up to the amount they invested in the dispute: Arkin v Borchard Lines Ltd [2005] EWCA 655, [2005] 1 WLR 3055. Even in jurisdictions where funders are not liable for adverse costs, commercial funders may indemnify their clients against an adverse costs order: $\mathrm{J}$ Kalajdzic et al, 'Justice for Profit: A Comparative Analysis of Australian, Canadian and U.S. Third Party Litigation Funding’ (2013) 61 The American Journal of Comparative Law 93, 142.
} 
litigants funding in whole or part their own access to justice. ${ }^{93}$ On the other hand, a guarantee that successful litigants will be made whole by their unsuccessful opponents leads to the distortions that beset full cost shifting and the recoverable CFA system. The goal of providing “full compensation” for claimants in a privately funded system can only be achieved at disproportionate costs to other litigants. Yet the fact that private funding model cannot deliver on this goal is not fatal to their viability, because making a successful litigant 'whole' is not a requirement of access to justice for the reasons outlined in part II.

Having identified what a private funding model should not be paying for, it is necessary to recall what it should pay for. The need for access to court to be within a reasonable time and at proportionate cost are firmly recognised in the rules of procedure and ECHR Art 6, but the process delivered by the English justice system is too often divorced from these requirements. As the Coventry case demonstrates, the English system delivers bucket loads of process dispensed by well-trained lawyers, but that is not the same thing as legal process. If an optimal legal process requires no more than a court decide a case using the most accurate procedure that can be provided at proportionate cost to the value of the dispute and within a reasonable time, the question in the Coventry case is not who should pay the hundreds of thousands of pounds to litigate the ordinary nuisance claim but how much process is due to decide the dispute? The answer is much less than the $£ 600,000$ worth probably incurred. The costs in Coventry were staggering. The claimant's base costs alone (excluding any success fee ${ }^{94}$ ) was more than four times $(£ 307,642)$ the diminution of value of the claimant's property due to the nuisance (estimated at no more than $£ 74,000$ ) and more than 14 times the actual damages awarded (£20,750). Moreover, these costs represent the

\footnotetext{
${ }^{93}$ In his final report into the costs of civil litigation Lord Justice Jackson concluded that it was untenable for defendants to go on bearing the risk that claimants suing them might be unsuccessful (given all the distortions it creates), and that successful claimants would need to bear some of the costs of funding their own access to justice: Jackson (n 4) Major Recommendations, pp xvi - xviii

94 The success fee was £215,007.
} 
costs of trial alone, excluding all appeals and, therefore, preclude any argument that the potential benefits to the public through the precedent making function of an appellate court might justify a higher level of investment and/or greater public subsidy of the dispute. ${ }^{95}$ Nor does the trial judgment purport to classify the case as a 'test case'; it appears to have been dealt with as a piece of standard contested litigation. ${ }^{96}$

The above analysis represents some qualified ${ }^{97}$ good news for advocates of private funding and governments and court managers looking to make savings. If one of the principal causes of the access to justice crisis has been too much investment i.e too much process rather than too little , the challenge of designing a private funding model that is accessible to all is not as herculean a task as a first reading of the Coventry case would suggest. That design task is examined further in the next sub-section.

\section{B. Objective 2: Paid for by whom and how? Designing a viable private funding model}

Any private funding model must determine the circumstances in which users should be required to pay for their own access to justice (properly defined), for others' access, and the extent of that contribution.

As a matter of economic logic, a viable private funding model ought to begin by using market forces to satisfy as much demand for legal assistance as possible. A commitment to access to justice for all without substantial public subsidy must be matched by policies that allow litigants and private legal providers to choose the most suitable funding methods and to

\footnotetext{
95 The Supreme Court noted the irony that it had delivered no fewer than three judgments in the case, which involved considerable cost, the last of which was a challenge to the cost orders made at first instance alleged to be excessive and a breach of the ECHR: ibid [1]

${ }^{96}$ Lawrence and Shields v Fen Tigers Ltd and Others [2011] EWHC 360 (QB), [2012] LLR 53

${ }^{97}$ See the discussion at in part IIabout the qualitative nature of legal process which means funding civil justice is not merely an exercise in cutting your coat according to your cloth.
} 
remove unnecessary restrictions on funding sources including third party funding. ${ }^{98}$ Greater choice of funding methods helps reduce costs, and promotes voluntary cross subsidization between users. Even economists, however, accept that a functioning free market will not satisfy all legitimate demand for legal assistance. ${ }^{99}$ While there are no truly free markets in legal assistance in advanced legal systems (as representation is regulated) the U.S experience suggests this assumption is sound. The U.S costs model provides a free market for the payment of qualified legal representation, requiring each litigant to pay for their own access (i.e. generally there is no cost shifting), and allows recourse to commercial funding. ${ }^{100}$ This is a good way of promoting proportionate costs, assuming litigants will act rationally and invest enough in the dispute to vindicate the right but no more than its value, because the litigant remains liable for the amount of resources they invest in a dispute. However, the costs of legal representation and litigation are still high ${ }^{101}$ suggesting that, at least in common law systems, there is a need for greater competition, and perhaps de-regulation, in the legal services market (or conversely price regulation of that market) ${ }^{102}$ and a need to reduce the cost of the legal process itself including less process. ${ }^{103}$ Moreover, because the viability of

\footnotetext{
${ }^{98}$ This is not a novel claim. According to Bentham : [S]o long as the expense of seeking relief at law [is expensive], the purpose of seeking that relief will of itself, independently of every other, afford a sufficient ground for allowing...every man to borrow money on any terms on which he can obtain it: J Bentham, Defence of Usury (1818) p 20.

${ }^{99}$ Competition and Markets Authority, Legal Services Market Study (Interim report, 8 July 2016) [1.10].

${ }^{100}$ Historically litigation funding in the United States was limited to lawyers only (contingency fees), but third party commercial funding is now gaining a foothold.

${ }^{101}$ A Justice Index produced by The National Center for Access to Justice (based at Cardozo Law School) found that many Americans, especially the disadvantaged, experience an 'access to justice' gap: see http://ncforaj.org/justiceindex/. In recognition of the problem the U.S Department of Justice has established an Access to Justice Initiative: https://www.justice.gov/atj

102 Some civil legal systems, such as Italy, regulate the cost of representation in court. The ECJ has rejected competition related challenges to the Italian rules, and even praised the Italian model: see e.g Commission $v$ Italy (C-565/08) (European Court of Justice Grand Chamber, 29 March 2011) ECR 2011, I-02101. For discussion from an economists' perspective on ways of improving competition and reducing the cost of legal services, see eg UK Competition \& Markets Authority, Legal Services Market Study: Final Report (December 2016) (recommending greater transparency on price and quality) and Australian Productivity Commission, Access to Justice Arrangements: Overview (No 72, 5 September 2014) (recommending partial practice licenses and 'unbundling' legal services).

103 Non funding related reforms aimed at making the civil justice system more accessible, but still consistent with the qualitative requirements of legal process, cannot be fully explored here. Innovative proposals to reduce litigation costs include the use of online courts which utilise software designed to limit the need for legal
} 
commercial funding is based on a combination of both merits and value of the claim, some

claimants with strong but low value claims will be denied access, which is a key motivation for allowing class actions. ${ }^{104}$ The U.S experience reveals probably the greatest challenge for designers of private funding models: working out how to make litigation over claims of modest value, or non-pecuniary claims, on behalf of people of limited means profitable enough for private providers to take on at all. Accepting that the market will not meet all legitimate demand for legal assistance, some mechanism for compulsory cross subsidization is needed to provide access to justice for the poor. Even the U.S has adopted some limited cross subsidization in the form of Equal Access to Justice Acts, ${ }^{105}$ which permit one way fee shifting so that claimants who successfully sue a governmental agency or large corporation can recover their fees. ${ }^{106}$

If voluntary cross subsidization is necessary but insufficient, can compulsory cross subsidization be made to work without distorting the legal process or the market for private legal representation so that it becomes unaffordable? In England, the system of recoverable CFAs had such disastrous effects, delivering access to justice for some at disproportionate expense to others, that it set back the cause of user based cross subsidization as demonstrated by the widespread opposition to enhanced court fees. But the problem with the CFA system is not the use of cross-subsidization per se, but the failure to properly regulate the costs that are subsidized.

\footnotetext{
assistance: Lord Justice Briggs, Civil Court Structure Review: Final Report (July 2016) Chapter 6 'The Online Court').

${ }^{104}$ As the U.S Supreme Court put it in Amchem Products Inc. v Windsor 521 US 591 (1997) at 617: 'The policy at the very core of the class action mechanism is to overcome the problem that small recoveries do not provide the incentive for any individual to bring a solo action prosecuting his or her rights.'

105 The first being the Federal Equal Access to Justice Act, Pub. L. No. 96-48)1, 94 Stat. 2325 (1980), reenacted in 1985 (codified as amended at 28 U.S.C. $§ 2412$ (2006) and 5 U.S.C. $§ 504$ (2006)).

106 The design, and limited scope of these Acts in practice, has been heavily criticized: see eg I Rosen-Zvi 'Just Fee Shifting' (2010) 37 Florida State U.Law Review 717.
} 
An example of a well-designed funding model, built largely on private finance and using both voluntary and compulsory cross-subsidization, is the German costs system. While Germany on employs cost shifting it is a very different system to the full cost shifting practiced in England. The German scheme provides for fixed recoverable costs, based on prescribed statutory fees for court costs ${ }^{107}$ and lawyer's fees ${ }^{108}$ which are calculated by reference to value of the claim, not the costs actually incurred by the successful party. ${ }^{109}$ The tariff provides for a no frills legal service, but allows litigants to pay for a higher level of service out of their own pockets, although there are restrictions on contingency fees. ${ }^{110}$

While compulsory cross subsidization is formally limited to the costs of parties to a dispute, the tariffs are partly set on the basis that fees earnt for mid-level and high-level cases allow a lawyer to cross subsidize low value cases with low profit margins. ${ }^{111}$ The German

${ }^{107}$ Court Fees Act (Gerichtskostengesetz (GKG))

${ }^{108}$ Lawyer's Remuneration Act (Rechtsanwaltsvergütungsgesetz (RVG))

${ }^{109}$ For helpful summaries see G Wagner 'Litigation costs and their recovery: the German experience' (2009) 28 CJQ 367; R Jackson, Review of Civil Litigation Costs: Preliminary Report (May 2009) chapter 55. One of the benefits of partial cost shifting is that it provides litigants with a viable means of enforcing or defending strong claims or defences knowing they can recover at least some of the cost from their opponent. Conversely it discourages abusive practice of litigants advancing weak claims or defences in the belief that it may not be economic for their opponents to contest them. Section13 of the RVG presently provides that when the value of the claim is less than $€ 500$, the fee shall be $€ 45$. For claims above $€ 500$, the fee increases from $€ 45$ as set out in the table below:

\begin{tabular}{|c|c|c|}
\hline $\begin{array}{c}\text { Value of the claim } \\
\text { is } \\
\text { up to } € \ldots\end{array}$ & $\begin{array}{c}\text {... for each additional amount of } € \ldots \text { or part } \\
\text { thereof }\end{array}$ & $\begin{array}{c}\text { the total fee shall increase by } \\
€ \ldots\end{array}$ \\
\hline 2,000 & 500 & 35 \\
\hline 10,000 & 1,000 & 51 \\
\hline 25,000 & 3,000 & 46 \\
\hline 50,000 & 5,000 & 75 \\
\hline 200,000 & 15,000 & 85 \\
\hline 500,000 & 30,000 & 120 \\
\hline $\begin{array}{c}\text { more than } \\
500,000\end{array}$ & 50,000 & 150 \\
\hline
\end{tabular}

${ }^{110}$ Which makes it more difficult for litigants to pay for their own access to justice than would otherwise be the case. In this regard, Germany provides a useful counter example to the accessibility problem in the U.S. In 2007 the German Constitutional Court struck down a law providing an outright ban on contingency fees as incompatible with the right of access to court: BVerfG, 1 BvR 2576/04 vom 12.12.2006. Combining the experience of both systems it seems total market freedom to pay for one's own legal costs cannot by itself guarantee access, but nor can a system of fully regulated cost shifting that maintains significant restrictions on the means of paying for one's own lawyer. Some mix of both is required.

${ }^{111} \mathrm{R}$ Jackson, Preliminary Report (n 7) chapter 55, para [2.6]. 
costs system also promotes widespread voluntary cross subsidization. Because court costs and adverse legal fees are proportionate and predictable, Germany has a vibrant 'before the event’ insurance market so that many German households have legal expenses insurance if they ever need to go to court. ${ }^{112}$

England has embraced compulsory cross subsidization to a greater degree than Germany. One of the funding models that replaced recoverable CFAs, Qualified One Way Cost Shifting, is partly based upon the principle that it is legitimate to require parties in an asymmetrical relationship to make an asymmetrical contribution to the costs of litigating their dispute. ${ }^{113}$ The system of enhanced fees goes further still and requires mandatory cross subsidization between litigants who have no relationship with each-other, other than their status as user. The UK Government has flagged, though not yet proceeded with, increasing court fees even further, thus deepening the degree of cross subsidization. ${ }^{114}$

What does the mixed experience of private funding models demonstrate? That some models unnecessarily increase the costs of access to justice, and deny it to some litigants, while others are capable of exerting a downward pressure on the costs of litigation and have the potential to facilitate access to justice for many more litigants than is presently the case. Different choices are available to those designing a private funding model, including the extent and method of compulsory cross-subsidization, as well as different methods for

\footnotetext{
${ }^{112}$ G Wagner (n 114) 385; R Jackson Preliminary Report, (n 7) ch 13, para [1.3]. The insurance market is a principal driver behind costs agreements that use the tariffs in the RVG for a litigant's own legal costs, and the RVG is also used as the basis to calculate legal aid fees. Figures from the German Federal Bureau of Statistics show that the number of legal aid applications is modest, and the success rate is high. In 2014 there were 103, 666 decisions on legal aid at first instance for all District and Regional Courts, of which 76, 783 were approved: Federal Bureau of Statistics, pp 26, 56. (Available at https://www.destatis.de/DE/Publikationen/Thematisch/Rechtspflege/GerichtePersonal/Zivilgerichte.html In German only)

${ }^{113}$ R Jackson (n 4) Ch.19 [4.7]-[4.10]. Under QOCS, which applies in personal injury cases, defendants pay for the claimants costs if the claimant successfully sues them, but claimants only pay the defendant's costs if they behaved unreasonably: CPR44.13-44.17. For a proposal that combines cross subsidy based on the outcome if the loser has more resources than the winner, see: I Rosen-Zvi, (n 107).

${ }^{114}$ The Government response to consultation on further fees proposals, Cm. 9181, (Ministry of Justice, December 2015) p14
} 
regulating commercial funding by lawyers and third parties. This paper has not sought to endorse any specific funding model - public or private - but drawing the threads together the key ingredients of a well-designed funding model are clear:

- Users need access to a range of funding methods to pay for their own access to justice (and regulatory restrictions should be limited to that what is strictly needed to prevent abuse of the legal process and exploitation of consumers). This, in turn, will promote voluntary cross subsidization amongst users through insurance and contingency funding mechanisms.

- Users, or those funding them, must contribute at least some of the cost of their own access to justice regardless of the result of the case. This rule is practically necessary to avoid moral hazard and the distortions it creates, and defensible in principle because litigating an arguable claim or defence, even if unsuccessfully, involves no wrong.

- In the absence of public subsidy, access to justice for all is only achievable if a private funding model incorporates some mechanism for compulsory subsidization. Requiring some users to pay for others' access to justice is defensible on distributive justice grounds.

- Any system of compulsory cross subsidization must be fully regulated: fees or costs orders payable must be predictable and proportionate to the value in dispute so that it does not impede the user's own right of access to justice.

- A well designed private funding model that incorporates elements of voluntary and compulsory cross subsidization is a necessary but not sufficient condition for promoting access to justice for all. Reforms to the underlying costs of legal representation and litigation are also necessary. 
Conclusion Participants in the civil justice funding debate often wrongly assume that the state has a duty to subsidise access to justice for all, and that only the state can fairly fund that system. Both the total level of subsidy and precise mix of public and private funding are questions of distributive justice, provided the system complies with the implied right of access to court and the qualitative and functional requirements of legal process. In too many cases like Coventry access to justice is denied because the system delivers too much rather than too little process. Once access to justice is correctly defined, it becomes possible to argue that civil justice can be fairly funded through private sources. While it would be brave to claim that a private funding model could deliver access to justice for all - given we have no direct example of it $^{115}$ - we know what the essential ingredients are of a well-designed private funding model. A model that provides users with the contractual freedom to pay for their own access, and incorporates a fully regulated system of predictable and proportionate compulsory cross subsidisation to pay for other's access, could at least provide a reasonable level of enforcement of rights for all parts of the population.

${ }^{115}$ Even the German system is partly dependent on public legal aid: see (n 113). 